\title{
Correction to: Thermodynamic Study of the Chlorine Content of Stainless Steel
}

\author{
ERICH KÖNIGSBERGER (D, KASTRIOT SPAHIU, and BJÖRN HERSCHEND
}

https://doi.org/10.1007/s11663-021-02109-6

(c) The Minerals, Metals \& Materials Society and ASM International 2021

Correction to:

Metallurgical and Materials Transactions B (2021)

https://doi.org/10.1007/s11663-021-02057-1

THIS erratum is to correct the title of Appendix A. The title contains the chemical formula of a chlorine isotope, which is written as ${ }^{36} \mathrm{CL}$. This is incorrect and should be changed to ${ }^{36} \mathrm{Cl}$. It should appear as: APPENDIX A: POTENTIAL SOURCES, ANALYSES, AND ENVIRONMENTAL IMPACT OF ${ }^{36} \mathrm{Cl}$ REPORTED IN THE LITERATURE
The original article has been corrected.

Publisher's Note Springer Nature remains neutral with regard to jurisdictional claims in published maps and institutional affiliations.

ERICH KÖNIGSBERGER is with the Chemistry Department, Murdoch University, Murdoch WA 6150, Australia. Contact e-mail: E.Koenigsberger@murdoch.edu.au KASTRIOT SPAHIU and BJÖRN HERSCHEND are with the SKB, Swedish Nuclear Fuel and Waste Management Company, Evenemangsgatan 13, Box 3091, 16903 Solna, Sweden.

The original article can be found online at https://doi.org/10.1007/ s11663-021-02057-1.

Article published online March 12, 2021. 